\title{
Current Avenues for COVID-19 Serology
}

\author{
Saumya Srivastava' Vidhi Jain ${ }^{1} \quad$ Vijaya Lakshmi Nag' \\ ${ }^{1}$ Department of Microbiology, All India Institute of Medical \\ Sciences, Jodhpur, Rajasthan, India \\ ${ }^{2}$ Department of Surgical Oncology, All India Institute of Medical \\ Sciences, Jodhpur, Rajasthan, India \\ ${ }^{3}$ Department of Paediatrics, All India Institute of Medical Sciences, \\ Jodhpur, Rajasthan, India
}

\author{
Sanjeev Misra² Kuldeep Singh ${ }^{3}$
}

Ann Natl Acad Med Sci (India):2020;2:87-90

\begin{abstract}
Address for correspondence Vijaya Lakshmi Nag, MD, Department of Microbiology, All India Institute of Medical Sciences, Jodhpur, Rajasthan, India (e-mail: vijayalakshmi005@gmail.com).
\end{abstract}

\author{
Abstract \\ Keywords \\ - rapid diagnostic tests \\ - COVID-19 serological \\ tests \\ - convalescent plasma \\ - immune status \\ - antibody test
}

Development of rapid, reliable, and easy diagnostic tests with high-throughput is the need of the hour for laboratories combating the COVID-19 pandemic. While realtime polymerase chain reaction (RT-PCR) is the gold standard for diagnosing active infections, it is expensive and time-consuming. Serological diagnostic assays with a premise to aid rapid contact tracing, immune status determination, and identification of potential convalescent plasma donors hold great promise. Timely diagnosis, effective treatment, and future prevention are key to management of COVID-19.

\section{Introduction}

The Coronavirus disease 2019 (COVID-19) caused by a novel coronavirus (SARS-CoV-2, previously known as 2019-nCoV) is a new pandemic, spreading across countries and threatening the world. ${ }^{1}$ Viral epidemics pose a serious threat to public health. In the last 20 years, several such epidemics, such as severe acute respiratory syndrome coronavirus (SARS-CoV) between 2002 and 2003, H1N1 influenza in 2009, Middle East Respiratory Syndrome Coronavirus (MERS-CoV) in 2012, have led to great human loss. Coronaviruses are enveloped positive sense RNA viruses with spiked projections on their surface, giving them a crowned appearance; hence, the name "Coronavirus."

The current pandemic began with a cluster of pneumonia cases reported from Wuhan, China, on December 31, 2019, resulting in the identification of a novel Coronavirus ${ }^{3}$ SARS-CoV-2 and its associated disease "COVID-19," an acronym of "Coronavirus disease 2019." On March 11, 2020, the WHO declared it as a pandemic. Despite social distancing and large-scale lockdowns, it has led to 310,801 deaths worldwide till May 16, 2020, ${ }^{4}$ requiring additional epidemiological solutions $\mathrm{s}^{5,6}$ to curtail its spread.

The microbiology laboratory is faced with multiple challenges related to reliable diagnosis and prognosis of COVID-19. Currently, the confirmation of active disease is approved by real-time polymerase chain reaction (RT-PCR) but this facility is expensive, time-consuming, and is only available in well-equipped laboratories with trained personnel. PCR results cannot predict past infection, immunity against the disease or prognosis. There is an urgent need for simpler, cheaper, and quicker point-of-care tests. Serological testing can enable testing of immune status, contact tracing and identification of potential convalescent plasma donors. Timely diagnosis, effective treatment, and future prevention are key to management of COVID-19.7

\section{Basis for Serological Testing and Immunoassays in COVID-19}

Serological testing for detection of antigen $(\mathrm{Ag})$ and/or antibodies $(\mathrm{Ab})$ is currently the focus of rapid diagnostic solutions for COVID-19. While RT-PCR for detection of true infection is clearly superior to serology, Ab testing may be a useful marker of immunity. IgM can be used to diagnose early infections, and IgG can be used as an indicator for current or past infections and postinfection immunity. These tests have a huge potential for establishing the epidemiology of COVID-198-12 as well (-Table 1). The challenges faced by developers of immunoassays are: (1) False negative results during the serological window period before IgM becomes detectable; (2) Asymptomatic infections leading to seropositivity with discordant PCR negativity, without a way to confirm the same; (3) Unknown baseline levels of 
Table 1 Some currently available immunodiagnostics to detect viral proteins or antibodies against SARS-CoV-2

\begin{tabular}{|c|c|c|c|c|}
\hline Test name & Test type & Sample source & Ig/protein detected & Manufacturer \\
\hline m2000 SARS- CoV-2 assay & $\begin{array}{l}\text { Chemiluminescent } \\
\text { microparticle } \\
\text { immunoassay }\end{array}$ & $\begin{array}{l}\text { Serum/plasma/ } \\
\text { whole blood }\end{array}$ & $\lg G$ & Abbot \\
\hline COVID-19 lgG/lgM LF & $\begin{array}{l}\text { Lateral flow } \\
\text { immunoassay }\end{array}$ & $\begin{array}{l}\text { Serum/plasma/ } \\
\text { whole blood }\end{array}$ & $\lg G / \lg M$ & Advagen Biotech \\
\hline COVID-19 lgM/lgG rapid test & $\begin{array}{l}\text { Lateral flow } \\
\text { immunoassay }\end{array}$ & $\begin{array}{l}\text { Serum/plasma/ } \\
\text { whole blood }\end{array}$ & $\lg G / \lg M$ & BioMedomics Inc. \\
\hline $\begin{array}{l}\text { IgG antibody test kit for novel } \\
\text { coronavirus 2019-nCoV }\end{array}$ & $\begin{array}{l}\text { Magnetic } \\
\text { particle-based } \\
\text { chemilumisence } \\
\text { assay }\end{array}$ & Serum & $\lg G$ & $\begin{array}{l}\text { Bioscience (Chongqing) } \\
\text { Diagnostic Technology } \\
\text { Co., Ltd. }\end{array}$ \\
\hline One-Step COVID-2019 test & $\begin{array}{l}\text { Lateral flow } \\
\text { immunoassay }\end{array}$ & $\begin{array}{l}\text { Serum/plasma/ } \\
\text { whole blood }\end{array}$ & $\lg G / \lg M$ & Celer Biotechnologia \\
\hline $\begin{array}{l}\text { KT-1033 EDI Novel Coronavirus } \\
\text { COVID-19 ELISA Kit }\end{array}$ & ELISA & Serum & $\lg G / \lg M$ & Epitope Diagnostics \\
\hline $\begin{array}{l}\text { VITROS- Immunodiagnostics } \\
\text { Products Anti- SARS-CoV-2 total } \\
\text { reagent pack }\end{array}$ & ELISA & Serum/blood & $\lg G / \lg M$ & Ortho Clinical Diagnostics \\
\hline Standard Q COVID-19 Ag & $\begin{array}{l}\text { Chromatographic } \\
\text { immunoassay }\end{array}$ & $\begin{array}{l}\text { Nasopharyngeal } \\
\text { swabs }\end{array}$ & Viral antigen & SD Biosensor \\
\hline
\end{tabular}

Abbreviation: ELISA, enzyme-linked immunosorbent assay.

potentially cross-reacting previous antiCoronavirus Abs in different populations; (4) Widely variable sensitivity and specificity values reported during field trials of most kits; ${ }^{13,14}$ (5) Lack of an established gold standard serological assay against SARS-CoV-2.

Current research has focused largely on the detection of either IgM or IgG Abs that are specific for various viral antigens including, but not limited to, the spike glycoprotein (S1 and S2 subunits, receptor-binding domain) and nucleocapsid protein. The methodology may be ELISA, immunochromatographic lateral flow assay, neutralization bioassay, specific chemosensors, or rapid Ag detection tests. Each of these formats brings advantages (speed, multiplexing, automation) and disadvantages (trained personnel, biosafety cabinets, dedicated laboratories). The Food and Drug Administration (FDA) granted Emergency Use Authorization (EUA) status to the first serology test, qSARS-CoV-2 IgG/IgM Rapid Test, manufactured by Cellex Inc. on April 1, 2020, ${ }^{14}$ but continues to allow clinical laboratories and commercial manufacturers to launch serological tests without an EUA status.

Lateral Flow Immunoassay: This test is typically a chromatographic assay that is small, portable, and used at the point-of-care. Being a rapid diagnostic test (RDT), the result can be obtained in 10 to 30 minutes. AntiCoronavirus Abs along with tracer Abs collect at the test band to produce a colored positive result. The test is cheap, without a need for trained staff but provides only qualitative results. A rapid bedside screening for infection may be possible in symptomatic patients using these Ab-based tests.
Rapid Antigen Detection Tests: While molecular methods are the current gold standard in diagnostic target detection, various rapid serological Ag detection tests using monoclonal Abs in different formats have been proposed. ${ }^{15,16}$ Such rapid tests employing colorimetry and chemiluminescence are available against SARS-CoV. ${ }^{17,18}$ A fluorescence-based lateral flow assay for the detection of SARS-CoV-2 nucleocapsid protein is currently under evaluation..$^{19}$ Some rapid Ag detection tests, using monoclonal anti-CoV antibodies, have been recently approved by ICMR for India (- Table 2 ).

Enzyme-linked Immunosorbent Assays (ELISA): ELISA, based on Abs or Ags attached to a solid surface, can be used to detect Ags or Abs with high-specificity. ${ }^{20,21}$ It can use in-house protocols or commercial reagent kits, has high throughput-run on 96 or 324-well plates, can be conducted on different sample types, namely, plasma or serum, takes just 1 to 5 hours for results, and is highly sensitive. ${ }^{17}$ Being a laboratory-based test, it requires dedicated instruments (e.g., plate reader) and trained laboratory staff. All laboratory procedures must be performed in a facility using procedures equivalent to a BSL-2, be based on a risk assessment, and conducted by trained personnel. Initial processing of samples from patients suspected to have COVID-19 infection, as well as any aerosol-generating procedures such as vortexing and ELISA plate washing, must be done in a biological safety cabinet. The scientists at ICMR-NIV, Pune, have developed and validated the completely indigenous IgG ELISA test for antibody detection for SARS-CoV-2. On external validation, the IgG test kit produced by ICMR-NIV, Pune, has been found to have sensitivity and specificity of $98.7 \%$ and $100 \%$, respectively. It is named 
Table 2 Rapid diagnostic kits approved by ICMR \& MoHFW in India (as on June 6, 2020)

\begin{tabular}{|c|c|c|}
\hline S. no. & Kit detail & Lot no. \\
\hline 1 & $\begin{array}{l}\text { COVID-19 IgM IgG rapid test: } \\
\text { BioMedomics (CE-IVD) }\end{array}$ & 20200226 \\
\hline 2 & $\begin{array}{l}\text { New Coronavirus (COVID-19) } \\
\text { IgG/IgM rapid test: Voxtur Bio } \\
\text { Ltd, India }\end{array}$ & PCCV200301S \\
\hline 3 & $\begin{array}{l}\text { COVID-19 IgM/lgG antibody } \\
\text { detection card test: VANGUARD } \\
\text { Diagnostics, India }\end{array}$ & RCOVID200301T \\
\hline 4 & $\begin{array}{l}\text { Makesure COVID-19 rapid test: } \\
\text { HLL Lifecare Limited, India }\end{array}$ & $\begin{array}{l}\text { CVCT030420 } \\
\text { CVCT0204203 } \\
\text { CVCT0104202 }\end{array}$ \\
\hline 5 & $\begin{array}{l}\text { YHLO iFlash-SARS-CoV-2 IgM } \\
\text { and IgG detection kit (addi- } \\
\text { tional equipment required): } \\
\text { CPC Diagnostics }\end{array}$ & 20200206 \\
\hline 6 & $\begin{array}{l}\text { ACCUCARE IgM/lgG lateral flow } \\
\text { assay kit: LABORATORY-CARE } \\
\text { Diagnostics (India Pvt. Ltd) }\end{array}$ & CVC 200401 \\
\hline 7 & $\begin{array}{l}\text { Abchek COVID-19 IgM/lgG } \\
\text { antibody rapid test: NuLifecare }\end{array}$ & $\begin{array}{l}\text { NUL/ } \\
\text { COV-19/R\&D/001 }\end{array}$ \\
\hline 8 & $\begin{array}{l}\text { One Step Coronavirus } \\
\text { (COVID-19) lgM/lgG antibody } \\
\text { test: Alpine Biomedicals }\end{array}$ & A10420 A20420 \\
\hline 9 & $\begin{array}{l}\text { COVID } 19 \mathrm{lgM} / \mathrm{lg} G \text { rapid } \\
\text { test kit; Medsource Ozone } \\
\text { Biomedicals (ver } 2.0 \text { ) }\end{array}$ & COV-002 \\
\hline 10 & $\begin{array}{l}\text { Immuno Quick rapid test for } \\
\text { detection of novel Coronavirus } \\
\text { (COVID-19) IgM/lgG antibodies: } \\
\text { Immuno Science India Pvt. Ltd }\end{array}$ & E142001 \\
\hline 11 & $\begin{array}{l}\text { Standard Q Covid-19 IgM/lgG } \\
\text { Duo test-One Step rapid anti- } \\
\text { body test: SD Biosensors }\end{array}$ & $\begin{array}{l}\text { E054002 } \\
\text { E054004 }\end{array}$ \\
\hline 12 & $\begin{array}{l}\text { COVID-19 IgG/IgM rapid test } \\
\text { kit Rafael Diagnostic: BMT } \\
\text { Diagnostics }\end{array}$ & $\begin{array}{l}\text { COV20030059 } \\
\text { COV20030059-1 }\end{array}$ \\
\hline 13 & $\begin{array}{l}\text { One Step COVID-19 IgM/lgG } \\
\text { antibody: SIDAK Life Care Pvt. } \\
\text { Ltd. }\end{array}$ & $\begin{array}{l}\text { COVID19S004A } \\
\text { COVID19S004B } \\
\text { COVID19S004C }\end{array}$ \\
\hline
\end{tabular}

Abbreviation: ICMR, Indian Council for Medical Research.

"COVID KAVACH ELISA," which is currently in the process of commercial production and distribution. ${ }^{22}$

Luminescent Immunoassay: Luminescent immunoassays comprise chemiluminescence and fluorescence technology to improve specificity. Cai et al have developed a peptide-based magnetic chemiluminescence enzyme immunoassay for diagnosis of COVID-19, and Diazyme Laboratories, Inc. (San Diego, California) announced the availability of two new fully automated serological tests for SARS-CoV- 2 that are run on the fully automated Diazyme DZ-lite 3000 Plus chemiluminescence analyzer. ${ }^{23,24}$

Biosensor Test: This technology uses broad-range PCR primers that target conserved regions of bacterial genomes, such as ribosomal sequences and essential protein-coding genes, and rapidly identifies a variety of pathogens without prior knowledge of the pathogen's nucleic acid sequence. The specific interaction of biomolecules can be converted into optical, electrical, enzymatic and other outcomes like surface plasmon resonance (SPR). An SPR-based biosensor had been developed for the diagnosis of SARS with a turnaround time of 10 minutes. ${ }^{25}$ Recently, PathSensors Inc. announced a CANARY biosensor to detect the novel SARS coronavirus. This platform utilizes a cell-based immunosensor that couples capture of the virus with signal amplification to provide a result in 3 to 5 minutes. ${ }^{15}$

Neutralization Assay: Neutralization assays are highly specific for detecting Abs that inhibit viral infection and cytopathic effects of viral replication. For this assay, patient's sample of whole blood, serum, or plasma are diluted and added at decreasing concentrations to the cell cultures. If neutralizing antibodies are present, they will bind and inactivate the virus. Their levels can be measured by determining the threshold at which they are able to prevent viral replication in the infected cell cultures. The time required for results is typically 3 to 5 days but recent advances have reduced this to hours. ${ }^{26,27}$ This type of testing requires Biosafety Level 3 (BSL3) cell culture facilities which is only available in reference laboratories. Despite these limitations, determination of neutralizing antibodies is important in the short-term for the therapeutic application of convalescent plasma and in the long-term for vaccine development.

\section{Conflict of Interest}

None declared.

\section{References}

1 Wang C, Horby PW, Hayden FG, Gao GF. A novel coronavirus outbreak of global health concern. Lancet 2020;395(10223):470-473

2 Zhu N, Zhang D, Wang W, et al. A novel Coronavirus from patients with pneumonia in China, 2019. NEJM 2020. Doi: NEJMoa2001017

3 Lu R, Zhao X, Li J, et al. Genomic characterisation and epidemiology of 2019 novel coronavirus: implications for virus origins and receptor binding. Lancet 2020;395(10224):565-574

4 Worldometer. Available at: https://www.worldometers.info/ coronavirus/. Accessed June 2, 2020

5 Wang CJ, Ng CY, Brook RH. Response to COVID-19 in Taiwan. JAMA 2020;323(14):1341

6 Lee VJ, Chiew CJ, Khong WX. Interrupting transmission of COVID-19: lessons from containment efforts in Singapore. J Travel Med 2020;27(3):taaa039

7 Look At Coronavirus In Focus - Infectious Diseases Hub. Available at: https://www.id-hub.com/2020/03/17/in-focuscoronavirus/. Accessed June 2, 2020

8 Serology-based tests for COVID-19. Johns Hopkins Center for Health. Available at: Security.www.centerforhealthsecurity. org/resources/COVID-19/serology/Serology- based-tests-forCOVID-19.html. Accessed April 26, 2020

9 Loeffelholz MJ, Tang YW. Laboratory diagnosis of emerging human coronavirus infections - the state of the art. Emerg Microbes Infect 2020;9(1):747-756

10 Udugama B, Kadhiresan P, Kozlowski HN, et al. Diagnosing COVID-19: the disease and tools for detection. ACS Nano 2020;14(4):3822-3835 
11 Zou L, Ruan F, Huang M, et al. SARS-CoV-2 viral load in upper respiratory specimens of infected patients. N Engl J Med 2020;382(12):1177-1179

12 Centerforhealthsecurity.org. Available at: https://www.centerforhealthsecurity.org/resources/COVID-19/COVID-19-factsheets/200228-Serology-testing-COVID.pdf. Accessed May 21, 2020

13 FDA. Available at: https://www.fda.gov/media/137111/download. Accessed June 2, 2020

14 Maxim LD, Niebo R, Utell MJ. Screening tests: a review with examples. Inhal Toxicol 2014;26(13):811-828

15 PathSensors. 2020. Pathsensors - Powered By CANARY Technology Available at: www.pathsensors.com. Accessed June 10, 2020

16 Khan S, Nakajima R, Jain A, et al. Analysis of serologic crossreactivity between common human Coronaviruses and SARS-CoV-2 using coronavirus antigen microarray. bioRxiv. Doi: $10.1101 / 2020.03 .24 .006544$

17 Diao B, Wen K, Chen J, et al. Diagnosis of acute respiratory syndrome Coronavirus 2 infection by detection of nucleocapsid protein. medRxiv. Doi: 10.1101/2020.03.07.20032524

18 Che XY, Qiu LW, Pan YX, et al. Sensitive and specific monoclonal antibody-based capture enzyme immunoassay for detection of nucleocapsid antigen in sera from patients with severe acute respiratory syndrome. J Clin Microbiol 2004;42(6):2629-2635

19 Yang X, Sun X, Chemiluminescent immunometric detection of Sars-Cov in sera as an early marker for the diagnosis of Sars. In: Akio T, Masako M, Larry JC, Philip ES, eds. Bioluminescence and Chemiluminescence. UK: Cambridge Research \& Technology Transfer Ltd; 2005
20 Liu W, Liu L, Kou G, et al. Evaluation of nucleocapsid and spike protein-based ELISAs for detecting antibodies against SARSCoV-2. J Clin Microbiol 2020. Doi: 10.1128/jcm.00461-20

21 Mizumoto K, Kagaya K, Zarebski A, Chowell G. Estimating the asymptomatic proportion of coronavirus disease 2019 (COVID-19) cases on board the Diamond Princess cruise ship, Yokohama, Japan, 2020. Euro Surveill 2020;25(10):2000180

22 COVID-19 | Indian Council of Medical Research | Government of India. Available at: https://main.icmr.nic.in/content/covid19. Accessed June 2, 2020

23 Cai XF, Chen J, Hu JL, et al. A peptide-based magnetic chemiluminescence enzyme immunoassay for serological diagnosis of Coronavirus disease 2019 (COVID-19) J Infect Dis 2020. Doi: 10.1093/infdis/jiaa243

24 Diazyme Laboratories, Inc. Announces Availability of COVID19 Antibody Tests. (2020). Available at: https://www. diazyme.com/diazyme- laboratories-inc-announces-availability-of-covid-19-antibody-tests. Accessed June 2, 2020

25 Park TJ, Hyun MS, Lee HJ, Lee SY, Ko S. A self-assembled fusion protein-based surface plasmon resonance biosensor for rapid diagnosis of severe acute respiratory syndrome. Talanta 2009; 79(2):295-301

26 Postnikova EN, Pettitt J, Van Ryn CJ, et al. Scalable, semi-automated fluorescence reduction neutralization assay for qualitative assessment of Ebola virus-neutralizing antibodies in human clinical samples. PLoS One 2019;14(8):e0221407

27 Carter LJ, Garner LV, Smoot JW, et al. Assay techniques and test development for COVID-19 diagnosis. ACS Cent Sci 2020; 6(5):591-605 